\title{
Maritimimonas rapanae gen. nov., sp. nov., isolated from gut microflora of the veined rapa whelk, Rapana venosa
}

Correspondence

Chi Nam Seong

scnu@scnu.ac.kr

\author{
Seong Chan Park, ${ }^{1}$ Keun Sik Baik, ${ }^{1}$ Duwoon $\mathrm{Kim}^{2}$ and Chi Nam Seong ${ }^{1}$ \\ 1Department of Biology, College of Life Science and Natural Resources, Sunchon National \\ University, Suncheon 540-742, Republic of Korea \\ ${ }^{2}$ Division of Food Science and Aqualife Medicine, Chonnam National University, Yeosu 550-749, \\ Republic of Korea
}

\begin{abstract}
A yellow-pigmented, Gram-negative, aerobic bacterial strain comprising rod-shaped cells devoid of flagellar and gliding motility, designated strain $\mathrm{A}_{31}{ }^{\top}$, was isolated from a veined rapa whelk (Rapana venosa) collected from the South Sea, Republic of Korea. Results from 16S rRNA gene sequence analysis indicated that the isolate belonged to the family Flavobacteriaceae; the highest level of nucleotide sequence similarity (92.6\%) was observed with Tenacibaculum aestuarii KCTC $12569^{\top}$. The predominant cellular fatty acids were iso- $\mathrm{C}_{15: 1} \mathrm{G}(24.2 \%)$, iso- $\mathrm{C}_{15: 0}$ $(20.1 \%)$ and iso- $\mathrm{C}_{17: 0} 3-\mathrm{OH}(11.2 \%)$. Flexirubin-type pigments were absent. The major isoprenoid quinone was MK-6. The DNA G $+\mathrm{C}$ content was $31.7 \mathrm{~mol} \%$. Data from a polyphasic taxonomic study suggested that the isolate represents a novel species in a new genus of the family Flavobacteriaceae, for which the name Maritimimonas rapanae gen. nov., sp. nov. is proposed. The type strain of Maritimimonas rapanae is $\mathrm{A}_{31}{ }^{\top}\left(=\mathrm{KCTC} 22186^{\top}=\mathrm{JCM} 15075^{\top}\right)$.
\end{abstract}

The family Flavobacteriaceae (Bernardet et al., 2002; Reichenbach, 1989) is one of the largest phylogenetic groups within the phylum Bacteroidetes (Garrity \& Holt, 2001). The family currently comprises more than 45 genera with validly published names, most of them originating from diverse environments including freshwater, brackish and marine waters, soil and epibenthic fauna. Members of the family are known to be proficient in degrading various biopolymers such as cellulose, chitin and pectin (Kirchman, 2002). Recently, phylogenetic analyses have revealed that many marine species in the family clustered together into a welldefined 'marine clade' (Bowman \& Nichols, 2005). These marine flavobacteria are known to play a role in the utilization of high-molecular-mass dissolved organic matter (Kirchman, 2002). In the course of our study on gut microflora of the veined rapa whelk (Rapana venosa), a yellow-pigmented bacterial strain, designated $\mathrm{A} 31^{\mathrm{T}}$, was isolated and subjected to taxonomic investigation. In this study, the description of a novel Flavobacterium-like bacterium that showed relatively low levels of $16 \mathrm{~S}$ rRNA gene sequence similarity to members of the family Flavobacteriaceae with validly published names is reported.

The GenBank/EMBL/DDBJ accession number for the $16 \mathrm{~S}$ rRNA gene sequence of strain $A 31^{\top}$ is EU290161.

A Fitch-Margoliash tree based on 16S rRNA gene sequences and an SEM of cells of strain $A 31^{\top}$ are available as supplementary material with the online version of this paper.
Strain $\mathrm{A} 31^{\mathrm{T}}$ was isolated using the standard dilution plating technique from a veined rapa whelk sample collected from the South Sea (Yeoja Bay; $34^{\circ} 44^{\prime} \mathrm{N} 127^{\circ}$ $44^{\prime}$ E) off the coast of the Republic of Korea during July 2008. Isolation was achieved using marine agar 2216 (MA; Difco) (Yang et al., 2007) at $25{ }^{\circ} \mathrm{C}$ for 7 days. The isolate was cultured routinely on MA and maintained at $-80{ }^{\circ} \mathrm{C}$ as a suspension in marine broth 2216 (MB; Difco) containing glycerol $(20 \%$, w/v).

Bacterial DNA preparation, PCR amplification and sequencing of the 16S rRNA gene were carried out as described previously (Chun \& Goodfellow, 1995). The resultant sequence of strain $\mathrm{A} 31^{\mathrm{T}}$ (1416 nt) was aligned manually against sequences obtained from GenBank. Phylogenetic trees were inferred from the regions available for all sequences (positions 22-1450; Escherichia coli numbering system) using the neighbour-joining (Saitou \& Nei, 1987) and Fitch-Margoliash (Fitch \& Margoliash, 1967) methods. Evolutionary distance matrices were generated according to Jukes \& Cantor (1969). The resultant neighbour-joining tree topology was evaluated by means of bootstrap analyses (Felsenstein, 1985) based on 1000 resamplings. Alignment and phylogenetic analyses were carried out using the program jPHYDIT (available at http://plaza.snu.ac.kr/ jchun/jphydit/) and PAUP 4.0 (Swofford, 1998) as described previously (Chun et al., 2000). 
Preliminary sequence comparison with 16S rRNA gene sequences held in GenBank indicated that our isolate showed low levels of similarity to strains of known species of the family Flavobacteriaceae. Strain $\mathrm{A} 31^{\mathrm{T}}$ was most closely related to members of the genera Tenacibaculum (90.1-92.6\% $16 \mathrm{~S}$ rRNA gene sequence similarity), Polaribacter (89.8-91.4\%), Lutibacter (90.9\%), Actibacter (91.2\%), Lutimonas (90.3\%) and Aestuariicola (90.2\%). No strains of other species with validly published names exceeded $90.5 \% 16 \mathrm{~S}$ rRNA gene sequence similarity with strain $\mathrm{A} 31^{\mathrm{T}}$. To elucidate the phylogenetic relationship between the novel isolate and other species of the family Flavobacteriaceae, phylogenetic trees were constructed by using two different tree-making algorithms. The neighbour-joining tree (Fig. 1) showed that strain $\mathrm{A} 31^{\mathrm{T}}$ formed a very robust clade with strains of Tenacibaculum, Polaribacter, Lutibacter, Lutimonas, Actibacter and Aestuariicola species, but could not be linked to any of the known genera in the family Flavobacteriaceae. The tree based on the Fitch-Margoliash method showed a similar topology (see Supplementary Fig. S1, available in IJSEM Online). The tree suggested that strain $\mathrm{A} 31^{\mathrm{T}}$ formed a monophyletic clade with those genera with $100 \%$ bootstrap support. Thus, strain $\mathrm{A} 31^{\mathrm{T}}$ should be recognized as a member of a new genus.

Cells grown for 7 days at $30{ }^{\circ} \mathrm{C}$ on MA were observed with phase-contrast (TMS-F; Nikon) and scanning electron (S4800; Hitachi) microscopes. Gliding motility was investigated by examining the edge of a hanging drop of fresh $\mathrm{MB}$ culture, as recommended by Bernardet et al. (2002). The requirement for sea salts (Sigma) for growth was determined at various concentrations (final concentrations of $0-12 \%$ in increments of $1 \%$ ) on nutrient agar (NA; Difco), trypticase soy agar (TSA; Difco), R2A agar (Difco) and ZoBell's agar (ZoBell, 1941; $5 \mathrm{~g}$ Bacto peptone, $1 \mathrm{~g}$ yeast extract, $0.1 \mathrm{~g}$ ferric citrate and $15 \mathrm{~g}$ Bacto agar in 11 distilled water). All media used in the physiological tests were supplemented with $4 \%$ sea salts unless MA or MB was used. The $\mathrm{pH}$ range for growth was determined in ZoBell's liquid medium. The medium was adjusted to $\mathrm{pH} 3-11$ (in increments of $1 \mathrm{pH}$ unit) by the addition of $\mathrm{HCl} / \mathrm{NaOH}$ and sterilized by filtration. Growth temperatures $\left(4-50{ }^{\circ} \mathrm{C}\right)$ and growth in an anaerobic chamber $\left(\mathrm{CO}_{2} / \mathrm{H}_{2} / \mathrm{N}_{2}, 10: 10: 80\right.$; Sheldon Manufacturing) were determined on MA after incubation for up to 1 week. The nature of growth on the surface, subsurface and bottom of tubes was determined in $\mathrm{MB}$ tubes cultivated for up to 14 days at $30{ }^{\circ} \mathrm{C}$. Catalase and oxidase activities were determined using $3 \%(\mathrm{v} / \mathrm{v})$ hydrogen peroxide and Kovács' reagent (Kovács, 1956), respectively. Acid production from glucose was tested as described by Yamaguchi \& Yokoe (2000). Nitrate reduction was tested in MB containing $0.2 \% \mathrm{KNO}_{3}$ (Skerman, 1967). $\mathrm{H}_{2} \mathrm{~S}$ production was determined on Kligler iron agar (Difco). Hydrolysis of CM-cellulose ( $1 \%, \mathrm{w} / \mathrm{v})$, casein [2\% (w/v) skimmed milk], chitin from crab shell $(0.5 \%$, w/v; Sigma), dextran ( $1 \%$, w/ v), egg yolk $(10 \%$, w/v), elastin $(0.5 \%$, w/v), starch $(0.2 \%$, $\mathrm{w} / \mathrm{v})$ and Tween $80(1 \%, \mathrm{w} / \mathrm{v})$ was tested as described by Smibert \& Krieg (1994) using MA as the basal medium.

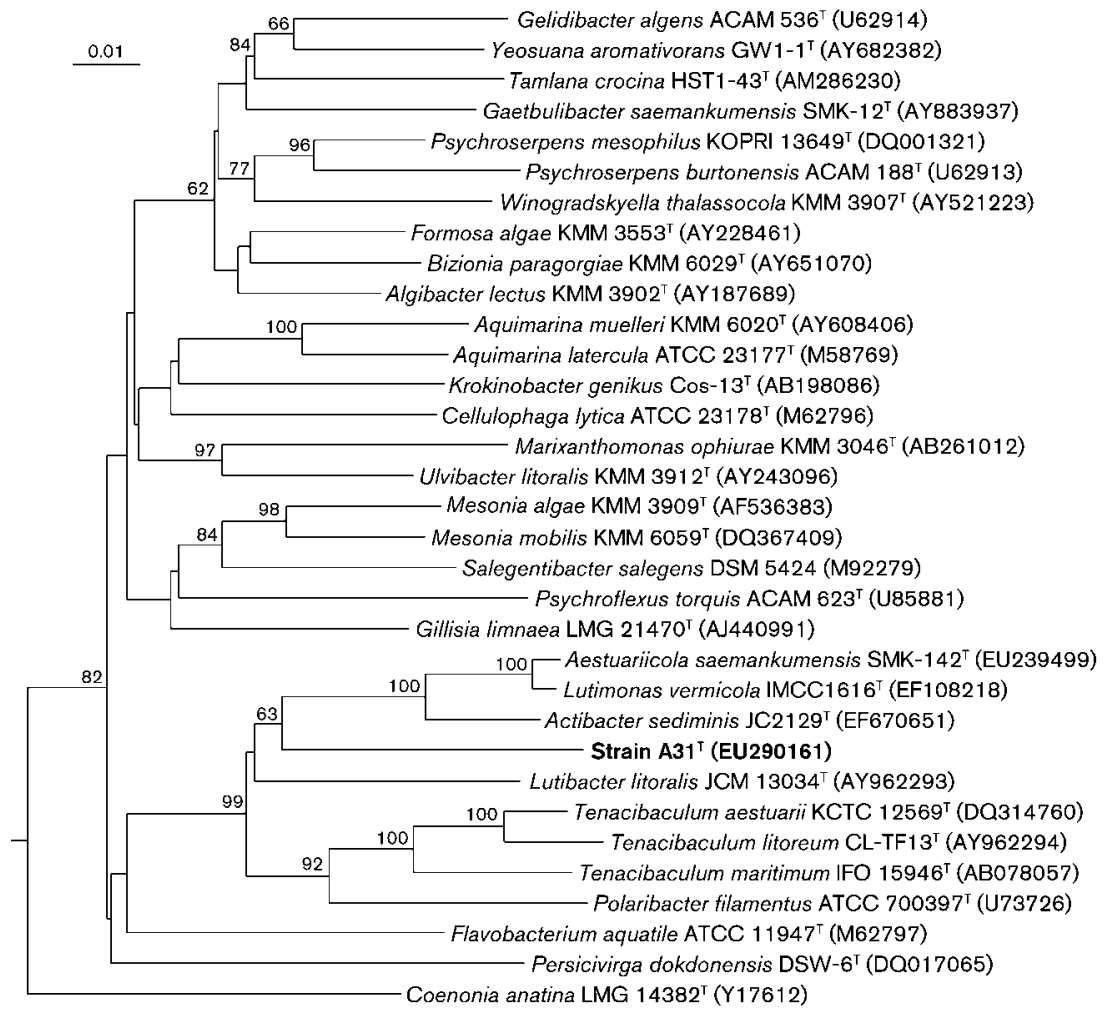

Fig. 1. Neighbour-joining tree based on nearly complete 16S rRNA gene sequences showing relationships between strain $A 31^{\top}$ and members of the family Flavobacteriaceae. Numbers at nodes are levels of bootstrap support (\%) based on neighbour-joining analyses of 1000 resampled datasets; only values greater than $50 \%$ are shown. The sequence of Bacteroides fragilis ATCC $25285^{\top}$ (GenBank accession no. X83935) was used as an outgroup (not shown). Bar, 0.01 substitutions per nucleotide position. 
Hydrolysis of L-tyrosine $(0.5 \%, \mathrm{w} / \mathrm{v})$ and xylan $(1 \%, \mathrm{w} / \mathrm{v})$ was tested using MA as the basal medium (Barrow \& Feltham, 1993). Cellulase activity was tested by observing the disintegration of filter paper in an MB culture (Smibert \& Krieg, 1994; Bernardet et al., 2002). DNase activity was determined with DNase test agar (Difco). Other biochemical tests and enzyme activity determinations were performed using the API 20E and API ZYM kits (bioMérieux) and GN2 MicroPlates (Biolog) prepared according to the manufacturers' instructions except that bacterial strains were suspended in distilled water supplemented with $4 \%$ sea salts. Antibiotic resistance was determined by the disc-diffusion method using commercial antibiotic-impregnated discs (BBL Becton Dickinson); after 5 days of incubation at $25{ }^{\circ} \mathrm{C}$ on $\mathrm{MA}$, results were interpreted according to the guidelines set forth by the
CLSI (2003). The presence of flexirubin-type pigments was examined as described by Bernardet et al. (2002).

Colonies of strain $\mathrm{A} 31^{\mathrm{T}}$ on MA were yellow-pigmented, convex and did not adhere to the agar. Flexirubin-type pigments were not detected. Physiological, morphological and biochemical characteristics are described in Table 1 and in the species description. A number of phenotypic characteristics clearly distinguished strain $\mathrm{A} 31^{\mathrm{T}}$ from members of other genera in the family Flavobacteriaceae. Strain $\mathrm{A} 31^{\mathrm{T}}$ was oxidase-positive, whereas strains of Lutibacter and Lutimonas are negative. Strain $\mathrm{A} 31^{\mathrm{T}}$ was unable to hydrolyse aesculin or starch, unlike most members of related genera. Significant differences between strain $\mathrm{A} 31^{\mathrm{T}}$ and members of other genera were found in the utilization of carbon sources.

Table 1. Differential phenotypic characteristics of strain $A 31^{\top}$ and members of related genera of the family Flavobacteriaceae

Taxa: 1, strain A31 ${ }^{\mathrm{T}}$; 2, Lutibacter litoralis CL-TF09 ${ }^{\mathrm{T}}$ (data from Choi \& Cho, 2006); 3, Tenacibaculum ( $n=14$; Choi et al., 2006; Frette et al., 2004; Heindl et al., 2008; Jung et al., 2006; Piñeiro-Vidal et al., 2008a, b; Sheu et al., 2007; Wang et al., 2008); 4, Polaribacter ( $n=6$; Gosink et al., 1998; Nedashkovskaya et al., 2005; Yoon et al., 2006); 5, Actibacter sediminis JC2129 ${ }^{\mathrm{T}}$ (Kim et al., 2008); 6, Lutimonas vermicola $\mathrm{IMCC} \mathrm{K}^{\mathrm{T}} \mathrm{T}^{\mathrm{T}}$ (Yang et al., 2007); 7, Aestuariicola saemankumensis SMK-142 ${ }^{\mathrm{T}}$ (Yoon et al., 2008). +, Positive; -, negative; v, variable; NA, data not available.

\begin{tabular}{|c|c|c|c|c|c|c|c|}
\hline Characteristic & 1 & 2 & 3 & 4 & 5 & 6 & 7 \\
\hline Cell morphology & $\mathrm{R}$ & $\mathrm{R}$ & $\mathrm{R}$ & $\mathrm{R} / \mathrm{F}$ & $\mathrm{R}$ & $\mathrm{R}$ & $\mathrm{R} / \mathrm{O} / \mathrm{C}$ \\
\hline Gliding motility & - & - & $\mathrm{V}$ & - & - & + & - \\
\hline Colony colour $\dagger$ & $\mathrm{Y}$ & $\mathrm{Y}$ & $\mathrm{Y} / \mathrm{PY}$ & $\mathrm{OR} / \mathrm{SP}$ & $\mathrm{Y}$ & $\mathrm{Y}$ & $\mathrm{Y}$ \\
\hline Sea salts requirement & + & + & $\mathrm{V}$ & $\mathrm{V}$ & - & $\mathrm{NA}$ & + \\
\hline \multicolumn{8}{|l|}{ Growth at: } \\
\hline pH 6 & + & - & $\mathrm{V}$ & NA & + & + & + \\
\hline $25^{\circ} \mathrm{C}$ & + & + & + & - & + & + & + \\
\hline $37{ }^{\circ} \mathrm{C}$ & + & - & $\mathrm{V}$ & - & + & + & - \\
\hline Oxidase & + & - & + & $\mathrm{V}$ & + & - & + \\
\hline Nitrate reduction & - & - & $\mathrm{V}$ & $\mathrm{v} \ddagger$ & - & - & - \\
\hline \multicolumn{8}{|l|}{ Hydrolysis of: } \\
\hline Aesculin & - & + & $-\S^{a}$ & $\mathrm{~V}$ & + & + & - \\
\hline Gelatin & + & + & $\mathrm{V}$ & $\mathrm{V}$ & + & + & - \\
\hline Starch & - & + & $\mathrm{V}$ & + & + & + & + \\
\hline \multicolumn{8}{|l|}{ Utilization of: } \\
\hline Sucrose & - & - & $\mathrm{V}$ & $\mathrm{V}$ & + & + & - \\
\hline L-Glutamate & + & - & $\mathrm{v}$ & $-\S^{b}$ & + & + & - \\
\hline L-Leucine & - & + & $\mathrm{vll}$ & $-\S^{b}$ & - & - & - \\
\hline L-Proline & + & - & $\mathrm{v}$ & $-\S^{b}$ & - & + & - \\
\hline Citrate & - & + & $\mathrm{V}$ & $-\S^{b}$ & + & + & - \\
\hline Pyruvate & - & + & $-\S^{c}$ & $-\S^{b}$ & + & - & - \\
\hline Succinate & - & + & $\mathrm{vg}$ & $-\S^{b}$ & - & + & - \\
\hline DNA G $+\mathrm{C}$ content $(\mathrm{mol} \%)$ & 31.7 & 33.9 & $29.8-35.2$ & $30.0-33.2$ & $43-45$ & 40.1 & 37.2 \\
\hline
\end{tabular}

${ }^{*} \mathrm{C}$, Cocci; F, filaments; O, ovals; $\mathrm{R}$, rods.

$\dagger$ †o, Orange; PY, pale yellow; SP, salmon pink; y, yellow.

$\ddagger$ All species except $P$. glomeratus are negative.

§Data not available for: $a$, T. gallaicum or T. soleae; b, P. butkevichii; c, T. aiptasiae, T. adriaticum, T. gallaicum or T. soleae.

IIAll type strains for which data are available are negative apart from that of $T$. skagerrakense, which is weakly positive. Data not available for $T$. gallaicum or T. soleae.

SAll type strains for which data are available are negative apart from that of T. adriaticum, which is positive. Data not available for T. aestuarii, T. aiptasiae, T. gallaicum, T. lutimaris or T. soleae. 
Table 2. Cellular fatty acid compositions (\%) of strain $A 31^{\top}$ and members of related genera in the family Flavobacteriaceae

Taxa: 1, strain A31 ${ }^{\mathrm{T}}$; 2, Lutibacter litoralis CL-TF09 ${ }^{\mathrm{T}}$ (data from Choi \& Cho, 2006); 3, Tenacibaculum ( $n=10$; Choi et al., 2006; Frette et al., 2004; Hansen et al., 1992; Jung et al., 2006; Piñeiro-Vidal et al., 2008b; Sheu et al., 2007; Wakabayashi et al., 1986; Yoon et al., 2005); 4, Polaribacter ( $n=6$; Gosink et al., 1998; Nedashkovskaya et al., 2005; Yoon et al., 2006); 5, Actibacter sediminis JC2129 ${ }^{\mathrm{T}}$ (Kim et al., 2008); 6, Lutimonas vermicola IMCC1616 ${ }^{\mathrm{T}}$ (Yang et al., 2007); 7, Aestuariicola saemankumensis SMK-142 ${ }^{\mathrm{T}}$ (Yoon et al., 2008). Fatty acid data are not available for T. amylolyticum, T. discolor, T. gallaicum or T. ovolyticum. Values are percentages of total fatty acids. tr, Trace amount $(<1 \%)$; ECL, equivalent chain-length. All strains studied except Polaribacter strains were grown on MA.

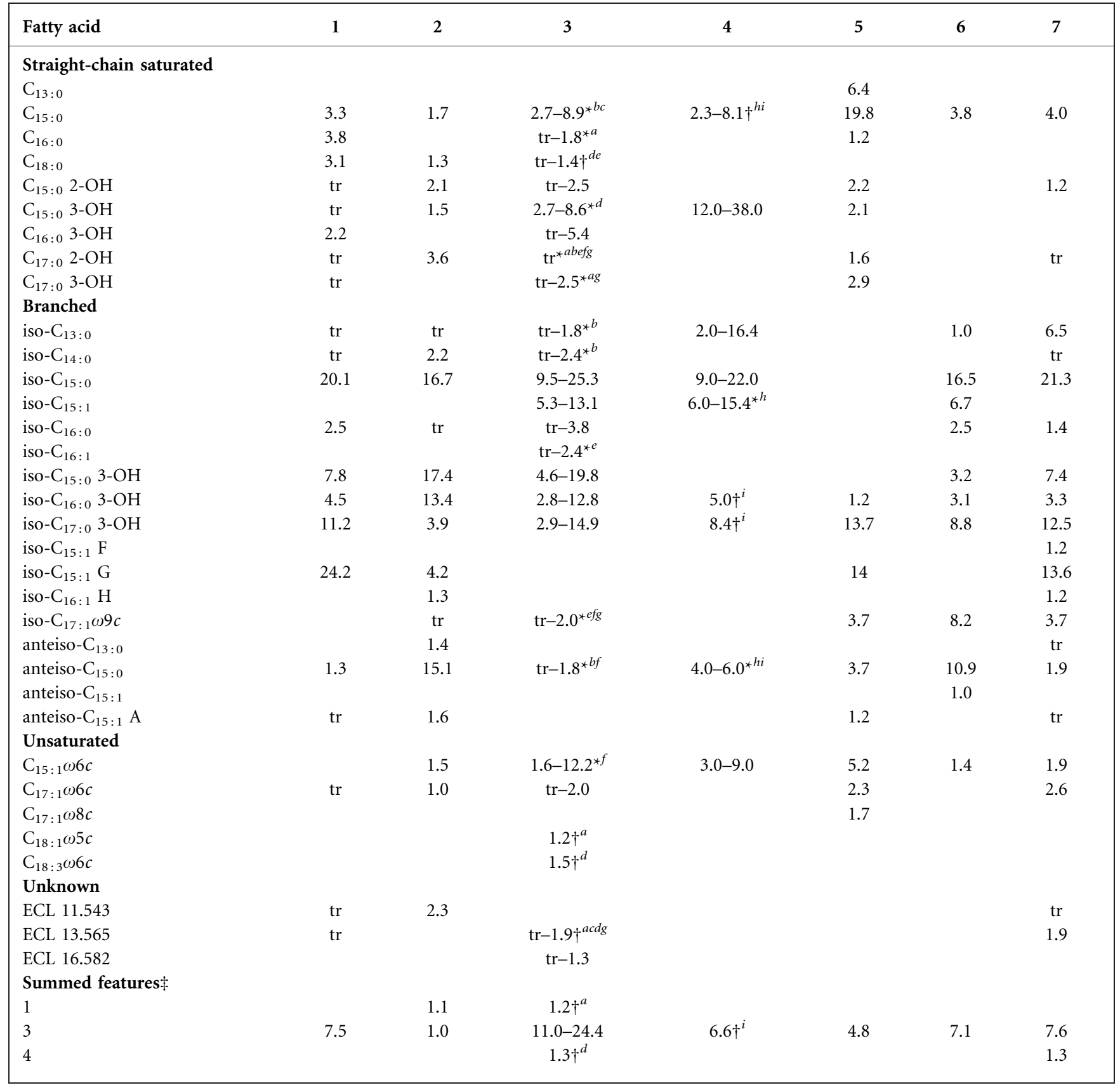

${ }^{\star}$ Not detected in the following species: $a$, T. adriaticum, $b$, T. aiptasiae; $c$, T. litopenaei; $d$, T. litoreum; e, T. maritimum; $f$, T. skagerrakense; g, T. soleae; $h$, P. butkevichii; $i, P$. dokdonensis.

$\dagger$ Detected in the following species: $a$, T. adriaticum; $c$, T. litopenaei; $d$, T. litoreum; e, T. maritimum; $g$, T. soleae; $h$, P. butkevichii; $i$, P. dokdonensis. $¥$ Summed features represent groups of two or three fatty acids that cannot be separated by GLC with the MIDI system. Summed feature 1 contained iso- $\mathrm{C}_{15: 1}$ and/or $\mathrm{C}_{13: 0} 3-\mathrm{OH}$; summed feature 3 contained $\mathrm{C}_{16: 1} \omega 7 c$ and/or iso- $\mathrm{C}_{15: 0} 2-\mathrm{OH}$; summed feature 4 contained iso- $\mathrm{C}_{17: 1} \mathrm{I}$ and/or anteiso- $\mathrm{C}_{17: 1} \mathrm{~B}$. 
Cells of strain $\mathrm{A} 31^{\mathrm{T}}$ grown on MA for 2 days at $30{ }^{\circ} \mathrm{C}$ were prepared (in duplicate) and analysed for fatty acids by GLC according to the instructions of the Microbial Identification System (MIDI, 1999). For G + C content calculations, DNA samples were prepared in triplicate and $\mathrm{G}+\mathrm{C}$ content was determined by the thermal denaturation method of Marmur \& Doty (1962). Isoprenoid quinones were isolated by using the method of Minnikin et al. (1984) and were analysed by HPLC (Varian) as described by Collins (1985).

The fatty acid profiles of strain $\mathrm{A} 31^{\mathrm{T}}$ and related members of the family Flavobacteriaceae are shown in Table 2 . The fatty acid profile of strain $\mathrm{A} 31^{\mathrm{T}}$ ( $>1.0 \%$ of total fatty acids) included the branched fatty acids iso- $\mathrm{C}_{15: 0}(20.1 \%)$, iso$\mathrm{C}_{16: 0}(2.5 \%)$ and anteiso- $\mathrm{C}_{15: 0}(1.3 \%)$, the hydroxy fatty acids iso- $\mathrm{C}_{17: 0} 3-\mathrm{OH}(11.2 \%)$, iso- $\mathrm{C}_{15: 0} 3-\mathrm{OH}(7.8 \%)$, iso$\mathrm{C}_{16: 0} 3-\mathrm{OH}(4.5 \%)$ and $\mathrm{C}_{16: 0} 3-\mathrm{OH}(2.2 \%)$, the straightchain fatty acids $\mathrm{C}_{16: 0}(3.8 \%), \mathrm{C}_{15: 0}(3.3 \%)$ and $\mathrm{C}_{18: 0}$ $(3.1 \%)$, the unsaturated fatty acid iso- $\mathrm{C}_{15: 1} \mathrm{G}(24.2 \%)$ and summed feature 3 (comprising iso- $\mathrm{C}_{15: 0}$ 2-OH and/or $\left.\mathrm{C}_{16: 1} \omega 7 c ; 7.5 \%\right)$. Significant differences were found in the levels of iso- $\mathrm{C}_{15: 1} \mathrm{G}$, anteiso- $\mathrm{C}_{15: 0}$ and summed feature 3 in strain $\mathrm{A} 31^{\mathrm{T}}$ and members of related genera. The DNA G $+\mathrm{C}$ content of strain $\mathrm{A} 31^{\mathrm{T}}$ was $31.7 \pm 0.4 \mathrm{~mol} \%$, a value within the range reported for members of the family Flavobacteriaceae. The predominant isoprenoid quinone of strain $\mathrm{A} 31^{\mathrm{T}}$ was MK-6, and small amounts of MK-7 and MK-8 were also found (MK-6/MK-7/MK-8 ratio $91: 5: 4$ ), as observed in all members of the family Flavobacteriaceae.

On the basis of the data from this polyphasic study, strain $\mathrm{A} 31^{\mathrm{T}}$ represents a novel species in a new genus in the family Flavobacteriaceae, for which the name Maritimimonas rapanae gen. nov., sp. nov. is proposed.

\section{Description of Maritimimonas gen. nov.}

Maritimimonas (Ma.ri'ti.mi.mo'nas. L. adj. maritimus of the sea, marine; L. fem. n. monas a unit, a monad; N.L. fem. n. Maritimimonas a monad from the sea, pertaining to the habitat of the animal that harboured the type species, a marine rock).

Cells are rod-shaped, non-flagellated, yellow-pigmented and non-gliding. Gram-negative. Aerobic, chemoheterotrophic and mesophilic. Oxidase- and catalase-positive. Spores are not formed. Flexirubin-type pigments are absent. The major isoprenoid quinone is MK-6. The predominant cellular fatty acids are iso- $\mathrm{C}_{15: 0}$, iso- $\mathrm{C}_{15: 1} \mathrm{G}$ and iso- $\mathrm{C}_{17: 0} 3-\mathrm{OH}$. Based on 16S rRNA gene sequence analysis, the genus is a member of the family Flavobacteriaceae. The type species is Maritimimonas rapanae.

\section{Description of Maritimimonas rapanae sp. nov.}

Maritimimonas rapanae (ra.pa' na.e. N.L. gen. n. rapanae of Rapana, the generic name of the mollusc from which the type strain was isolated).

Cells are $0.3-0.4 \mu \mathrm{m}$ wide and $0.8-1.2 \mu \mathrm{m}$ long and sometimes show filamentous growth (Supplementary
Fig. S2). Colonies on MA are circular, smooth, convex, yellow-pigmented and glistening with entire margins, do not adhere to the agar and are approximately $2.0 \mathrm{~mm}$ in diameter after 7 days at $30{ }^{\circ} \mathrm{C}(\mathrm{pH} \mathrm{7})$. Growth occurs at 10$37{ }^{\circ} \mathrm{C}$ (optimum, $30{ }^{\circ} \mathrm{C}$ ) and $\mathrm{pH}$ 5-9 (optimum, $\mathrm{pH} 7$ ). Growth occurs in media (ZoBell's, TSA, R2A and NA) containing 3-6\% sea salts (optimum, 4-5\%), but not in media supplemented with $\mathrm{NaCl}(1-12 \%)$ alone. Cells grow in the bottom of tubes as viscid sediments. Nitrate is not reduced to nitrite. Indole and $\mathrm{H}_{2} \mathrm{~S}$ are not produced. Gelatin is degraded, but aesculin, DNA, agar, casein, CM-cellulose, crystalline cellulose (filter paper), chitin, starch and Tween 80 are not. In API ZYM tests, alkaline phosphatase, esterase (C4), esterase lipase (C8), $\alpha$-chymotrypsin, acid phosphatase, naphthol-AS-BI-phosphohydrolase, leucine arylamidase and valine arylamidase activities are present, cystine arylamidase and trypsin activities are weakly positive and $\alpha$ glucosidase, lipase (C14), $\alpha$-galactosidase, $\beta$-galactosidase, $\beta$-glucosidase, $\beta$-glucuronidase, $N$-acetyl- $\beta$-glucosaminidase, $\alpha$-fucosidase and $\alpha$-mannosidase activities are absent. Acid is produced from glucose. In GN2 MicroPlate (Biolog) tests, D-glucose, L-alanine, L-alanyl glycine, L-glutamic acid, glycyl L-glutamic acid, hydroxy-L-proline, L-ornithine, Lserine and L-threonine are utilized. Sensitive to ( $\mu$ g per disc, unless indicated) chloramphenicol (30), erythromycin (15), tetracycline (30) and vancomycin (30); resistant to amikacin (30), ampicillin (10), gentamicin (10), kanamycin (30), nalidixic acid (30), penicillin (10 IU), polymyxin B (300 IU) and streptomycin (10). The predominant cellular fatty acids are iso- $\mathrm{C}_{15: 1} \mathrm{G}$, iso- $\mathrm{C}_{15: 0}$, iso- $\mathrm{C}_{17: 0} 3-\mathrm{OH}$, iso- $\mathrm{C}_{15: 0} 3-\mathrm{OH}$ and summed feature 3 (comprising iso- $\mathrm{C}_{15: 0} 2-\mathrm{OH}$ and/or $\left.\mathrm{C}_{16: 1} \omega 7 c\right)$. The DNA $\mathrm{G}+\mathrm{C}$ content of the type strain is $31.7 \mathrm{~mol} \%$.

The type strain is $\mathrm{A} 31^{\mathrm{T}}\left(=\mathrm{KCTC} 22186^{\mathrm{T}}=\mathrm{JCM} 15075^{\mathrm{T}}\right.$ ), isolated from a sample from a veined rapa whelk (Rapana venosa) collected from the South Sea, Republic of Korea.

\section{Acknowledgements}

This research was supported by the 21C Frontier Microbial Genomics and Applications Center Program, Ministry of Education, Science \& Technology, Republic of Korea.

\section{References}

Barrow, G. I. \& Feltham, R. K. A. (1993). Cowan and Steel's Manual for the Identification of Medical Bacteria, 3rd edn. Cambridge: Cambridge University Press.

Bernardet, J.-F., Nakagawa, Y. \& Holmes, B. (2002). Proposed minimal standards for describing new taxa of the family Flavobacteriaceae and emended description of the family. Int J Syst Evol Microbiol 52, 1049-1070.

Bowman, J. P. \& Nichols, D. S. (2005). Novel members of the family Flavobacteriaceae from Antarctic maritime habitats including Subsaximicrobium wynnwilliamsii gen. nov., sp. nov., Subsaximicrobium saxinquilinus sp. nov., Subsaxibacter broadyi gen. nov., sp. nov., Lacinutrix copepodicola gen. nov., sp. nov., and novel species of the genera Bizionia, Gelidibacter and Gillisia. Int J Syst Evol Microbiol 55, 1471-1486. 
Choi, D. H. \& Cho, B. C. (2006). Lutibacter litoralis gen. nov., sp. nov., a marine bacterium of the family Flavobacteriaceae isolated from tidal flat sediment. Int J Syst Evol Microbiol 56, 771-776.

Choi, D. H., Kim, Y.-G., Hwang, C. Y., Yi, H., Chun, J. \& Cho, B. C. (2006). Tenacibaculum litoreum sp. nov., isolated from tidal flat sediment. Int J Syst Evol Microbiol 56, 635-640.

Chun, J. \& Goodfellow, M. (1995). A phylogenetic analysis of the genus Nocardia with 16S rRNA gene sequences. Int J Syst Bacteriol 45, 240-245.

Chun, J., Bae, K. S., Moon, E. Y., Jung, S. O., Lee, H. K. \& Kim, S. J. (2000). Nocardiopsis kunsanensis sp. nov., a moderately halophilic actinomycete isolated from a saltern. Int J Syst Evol Microbiol 50, 1909-1913.

CLSI (2003). Performance standards for antimicrobial disk susceptibility tests, 8th edn. Approved Standard M2-A8. Wayne, PA: Clinical Laboratory Standards Institute.

Collins, M. D. (1985). Analysis of isoprenoid quinones. Methods Microbiol 18, 329-366.

Felsenstein, J. (1985). Confidence limits on phylogenies: an approach using the bootstrap. Evolution 39, 783-791.

Fitch, W. M. \& Margoliash, E. (1967). Construction of phylogenetic trees: a method based on mutation distances as estimated from cytochrome $c$ sequences is of general applicability. Science 155, 279-284.

Frette, L., Jørgensen, N. O. G., Irming, H. \& Kroer, N. (2004). Tenacibaculum skagerrakense sp. nov., a marine bacterium isolated from the pelagic zone in Skagerrak, Denmark. Int J Syst Evol Microbiol 54, 519-524.

Garrity, G. M. \& Holt, J. G. (2001). The road map to the Manual. In Bergey's Manual of Systematic Bacteriology, 2nd edn, vol. 1, pp. 119166. Edited by D. R. Boone, R. W. Castenholz \& G. M. Garrity. New York: Springer.

Gosink, J. J., Woese, C. R. \& Staley, J. T. (1998). Polaribacter gen. nov., with three new species, $P$. irgensii sp. nov., $P$. franzmannii sp. nov. and $P$. filamentus sp. nov., gas vacuolate polar marine bacteria of the Cytophaga-Flavobacterium-Bacteroides group and reclassification of 'Flectobacillus glomeratus' as Polaribacter glomeratus comb. nov. Int J Syst Bacteriol 48, 223-235.

Hansen, G. H., Bergh, Ø., Michaelsen, J. \& Knappskog, D. (1992). Flexibacter ovolyticus sp. nov., a pathogen of eggs and larvae of Atlantic halibut, Hippoglossus hippoglossus L. Int J Syst Bacteriol 42, 451-458.

Heindl, H., Wiese, J. \& Imhoff, J. F. (2008). Tenacibaculum adriaticum sp. nov., from a bryozoan in the Adriatic Sea. Int J Syst Evol Microbiol 58, 542-547.

Jukes, T. H. \& Cantor, C. R. (1969). Evolution of protein molecules. In Mammalian Protein Metabolism, vol. 3, pp. 21-132. Edited by H. N. Munro. New York: Academic Press.

Jung, S.-Y., Oh, T.-K. \& Yoon, J.-H. (2006). Tenacibaculum aestuarii sp. nov., isolated from a tidal flat sediment in Korea. Int J Syst Evol Microbiol 56, 1577-1581.

Kim, J.-H., Kim, K.-Y., Hahm, Y.-T., Kim, B.-S., Chun, J. \& Cha, C.-J. (2008). Actibacter sediminis gen. nov., sp. nov., a marine bacterium of the family Flavobacteriaceae isolated from tidal flat sediment. Int J Syst Evol Microbiol 58, 139-143.

Kirchman, D. L. (2002). The ecology of Cytophaga-Flavobacteria in aquatic environments. FEMS Microbiol Ecol 39, 91-100.

Kovacs, N. (1956). Identification of Pseudomonas pyocyanea by the oxidase reaction. Nature 178, 703.

Marmur, J. \& Doty, P. (1962). Determination of the base composition of deoxyribonucleic acid from its thermal denaturation temperature. J Mol Biol 5, 109-118.
MIDI (1999). Sherlock Microbial Identification System Operating Manual, version 3.0. Newark, DE: MIDI, Inc.

Minnikin, D. E., O'Donnell, A. G., Goodfellow, M., Alderson, G., Athalye, M., Schaal, A. \& Parlett, J. H. (1984). An integrated procedure for the extraction of bacterial isoprenoid quinones and polar lipids. J Microbiol Methods 2, 233-241.

Nedashkovskaya, O. I., Kim, S. B., Lysenko, A. M., Kalinovskaya, N. I., Mikhailov, V. V., Kim, I. S. \& Bae, K. S. (2005). Polaribacter butkevichii sp. nov., a novel marine mesophilic bacterium of the family Flavobacteriaceae. Curr Microbiol 51, 408-412.

Piñeiro-Vidal, M., Riaza, A. \& Santos, Y. (2008a). Tenacibaculum discolor sp. nov. and Tenacibaculum gallaicum sp. nov., isolated from sole (Solea senegalensis) and turbot (Psetta maxima) culture systems. Int J Syst Evol Microbiol 58, 21-25.

Piñeiro-Vidal, M., Carballas, C. G., Gómez-Barreiro, O., Riaza, A. \& Santos, Y. (2008b). Tenacibaculum soleae sp. nov., isolated from diseased sole (Solea senegalensis Kaup). Int J Syst Evol Microbiol 58, 881-885.

Reichenbach, H. (1989). Order I. Cytophagales Leadbetter 1974, $99^{\mathrm{AL}}$. In Bergey's Manual of Systematic Bacteriology, vol. 3, pp. 2011-2013. Edited by J. T. Staley, M. P. Bryant, N. Pfennig \& J. C. Holt. Baltimore: Williams \& Wilkins.

Saitou, N. \& Nei, M. (1987). The neighbor-joining method: a new method for reconstructing phylogenetic trees. Mol Biol Evol 4, 406-425.

Sheu, S.-Y., Lin, K.-Y., Chou, J.-H., Chang, P.-S., Arun, A. B., Young, C.-C. \& Chen, W.-M. (2007). Tenacibaculum litopenaei sp. nov., isolated from a shrimp mariculture pond. Int J Syst Evol Microbiol 57, 1148-1153.

Skerman, V. B. D. (1967). A Guide to the Identification of the Genera of Bacteria, 2nd edn. Baltimore: Williams \& Wilkins.

Smibert, R. M. \& Krieg, N. R. (1994). Phenotypic characterization. In Methods for General and Molecular Bacteriology, pp. 607-654. Edited by P. Gerhardt, R. G. E. Murray, W. A. Wood \& N. R. Krieg. Washington, DC: American Society for Microbiology.

Swofford, D. L. (1998). Phylogenetic analysis using parsimony (PAUP), version 4. Sunderland, MA: Sinauer Associates.

Wakabayashi, H., Hikida, M. \& Masumura, K. (1986). Flexibacter maritimus sp. nov., a pathogen of marine fishes. Int J Syst Bacteriol 36, 396-398.

Wang, J.-T., Chou, Y.-J., Chou, J.-H., Chen, C. A. \& Chen, W.-M. (2008). Tenacibaculum aiptasiae sp. nov., isolated from a sea anemone Aiptasia pulchella. Int J Syst Evol Microbiol 58, 761-766.

Yamaguchi, S. \& Yokoe, M. (2000). A novel protein-deamidating enzyme from Chryseobacterium proteolyticum sp. nov., a newly isolated bacterium from soil. Appl Environ Microbiol 66, 3337-3343.

Yang, S.-J., Choo, Y.-J. \& Cho, J.-C. (2007). Lutimonas vermicola gen. nov., sp. nov., a member of the family Flavobacteriaceae isolated from the marine polychaete Periserrula leucophryna. Int J Syst Evol Microbiol 57, 1679-1684.

Yoon, J.-H., Kang, S.-J. \& Oh, T.-K. (2005). Tenacibaculum lutimaris sp. nov., isolated from a tidal flat in the Yellow Sea, Korea. Int J Syst Evol Microbiol 55, 793-798.

Yoon, J.-H., Kang, S.-J. \& Oh, T.-K. (2006). Polaribacter dokdonensis sp. nov., isolated from seawater. Int J Syst Evol Microbiol 56, 12511255.

Yoon, J.-H., Kang, S.-J., Jung, Y.-T. \& Oh, T.-K. (2008). Aestuariicola saemankumensis gen. nov., sp. nov., a member of the family Flavobacteriaceae, isolated from tidal flat sediment. Int J Syst Evol Microbiol 58, 2126-2131.

ZoBell, C. E. (1941). Studies on marine bacteria. I. The cultural requirements of heterotrophic aerobes. J Mar Res 4, 41-75. 